Славица Петровска

\title{
ФОЛКЛОРНАТА ЕСТЕТИКА ВО РЕВОЛУЦИОНЕРНО АНГАЖИРАНАТА ДРАМА ОД КРАЈОТ НА ХІХ И НА ПОЧЕТОКОТ НА ХX ВЕК
}

\begin{abstract}
Апстракт: Македонските драмски текстови, создадени во периодот од крајот на XIX и во почетокот на XX век, и покрај доминантните револуционернополитичките идејни тенденции, изобилуваат и со бројни фолклорни естетски елементи. Револуционерниот дух се јавува и како лајтмотив на книжевен план, додека фолклорните елементи најчесто имаат секундарна улога во драмското дејство. Со употребата на народната мудрост, авторите се обидуваат да ја засилат естетската вредност на драмите преку внесување: бројни песни, благослови, клетви и поздрави, карактеристични за македонскиот народ од тој период. Преку внесувањето на фолклорните и битови елементи во револуционерните драми, драмските автори полесно успевале да ја остварат својата главна цел - афирмација на македонскиот културен и национален идентитет.
\end{abstract} идентитет.

Клучни зборови: македонска драма, естетика, фолклор, народни песни,

Сложената општествено-политичка ситуација во Македонија од крајот на XIX и на почетокот на XX век дале автентични насоки во духовниот и во културниот живот, кои иницирале специфични особености во поглед на новите идејни и естетски тенденции и во драмската книжевност. Во оваа епоха драмата претставува доминантен книжевен жанр, којшто извршил силно влијание врз будењето на националната свест. Во овој круцијален период од македонската историја започнува новата фаза на македонскиот културен развој, којшто иницира суштински промени во поглед на: духовниот, политичкиот и општествениот живот. Драмата создавана на македонски терен во овој период претставува продукт на карактеристичните општественополитички, духовни и културолошки можности, кои ја формираат историската рамка на епохата, поставувајќи се како ориентир за културниот развој на општеството и за конкретните афинитети на тоа време.

Во периодот од крајот на XIX и на почетокот на XX век на македонската драмска книжевна сцена се јавуваат нови естетско-стилски обележја, кои ѝ даваат посебна одлика на првата развојна фаза на современата македонска драма. Главните фактори, коишто го одредуваат естетскиот модел на овие драми, ги наоѓаме во револуционерно-политичките идејни тенденции, кои, во дадената епоха, ја диктирале духовната и културната динамика на општествениот развој. Овие револуционерно-политички ангажирани драми го потврдуваат континуитетот на македонското драмско творештво, а нивните естетски вредности се адекватни на времето и на условите во кои се создавани 
и изведувани. Оваа драмска продукција изобилува со автентични историски и фолклорни сведоштва на македонскиот народ и претставуваат постулат за формирање на нови естетски диспозиции. Формирајќи еден свој специфичен книжевен модел, тие се развиле естетски и идејно во духот на револуцијата и народниот бит.

Периодот од крајот на XIX и на почетокот на XX век се одликува со карактеристични книжевни тенденции и развојни определби. Речиси сите драми од овој период имаат актуелен карактер, што укажува на тоа дека авторите се стремеле да го претстават нивното време со сите негови општествени и политички проблеми. Книжевните остварувања ги откриваат основните насоки во духовниот развој на дадената епоха, кои биле формирани под влијание на општествено-политичките и на културолошките околности (Јакимовска-Тошиќ, 2013, 13). Преку овие драмски остварувања ги откриваме основните насоки во духовниот, естетскиот и книжевниот развој на епохата, бидејќи тие биле основното средство за книжевна комуникација. Нивната содржина во најголема мера ги отсликуваат развојните линии на книжевноста од тоа време. Во нив се забележува револуционерниот израз, со истакнување на сопствените и колективните доживувања на ликовите, преку што се барало начин за критика и бунт против актуелните збиднувања на општествен план.

Од овој период се издвојуваат значајни книжевни имиња, кои, преку своите заложби, оставиле силен впечаток на книжевен и на општествен план. Тие се обидувале, преку начинот на изразување, јазикот и темите што ги разработувале, да се доближат до обичниот човек и до неговите проблеми. Но, освен теми од секојдневните патила, во голема мера биле застапени и историско-патриотски теми, како и теми со кои се прокламирал новиот активизам во борбата за идентитетска афирмација. Драмите создавани во овој општествено-политички бурен период биле создавани главно со една цел афирмација на ослободително-револуционерните идеи. Овие драмски текстови кон гледачите не требало да предизвикаат само чувства на убавина и на естетско доживување, туку и да побудат револуционерни чувства и стремеж за истакнување на својата национална и културна посебност. Така гледачите не се само неми набљудувачи, туку и активни учесници во ширењето на револуционерната мисла. Преку нив, авторите се стремеле да го пренесат болното историско минато и актуелните политички и општествени проблеми не осврнувајќ́ се премногу на изразот, на уметничките впечатоци, туку на претставувањето на македонската трагедија пред светот.

Преминот од народната кон книжевната литература бил под директно влијание на општествено-културните околности во Македонија, а како резултат на тоа се јавува една нова реалистичка книжевност, која се карактеризира со присуство на фолклорни и борбено-револуционерни елементи: „Ваквиот реализам во македонската книжевност е еден нужен премин кон помодерните методолошки пристапи и стилски модели во рамките на остварувањето на реалистичкиот естетски идеал“ (Друговац, 1990, 41). Општествено-политичките случувања на територијата на Македонија силно се одразиле врз тематско-мотивските преокупации во драмските текстови. Ревлоуционерната борба е главниот лајтмотив на сите драми, преплетена со 
мотиви и содржини од секојдневниот живот на поробениот народ, неговите фолклорни и духовни белези, неговата болка и стремеж за подобро утре. Пишувани најчесто во служба на револуционерната борба, кај повеќето драми не се забележуваат некои поголеми уметнички вредности. Сепак, преку внесувањето на фолклорни елементи, коишто, на некој начин, го отсликуваат животот и духовните состојби на народот, во нив се инкорпорирало поголемо естетско доживуање. Народот е творец, носител, чувар на јазикот и на културата, каде што и единствено може да се одвива процесот на уметничкото творење. Тој е цел на уметноста, нејзина последна адреса и потрошувач, затоа адаптирањето на драмските дела со битот на народот бил од круцијално значење за популаризацијата на револуционерните драмски дела. Популарноста и достапноста е својство на уметничкото творештво, кое не се постигнува со упростување на структурата на ликовите во делото, туку со нејзино совпаѓање со системот на народното мислење, неговите сфаќања, начин на говор и размислување: „При тоа авторот (уметникот) не се адаптира на масовниот аудиториум, туку ја издигнува неговата уметничка перцепција, го воспитува естетскиот вкус“" (Борев, 2008, 182).

Естетската вредност на уметничкото дело е променлива категорија. Таа се менува во зависност од националниот карактер на народот и од традиционалните форми на изразување. Временските, општествените, историските и културните промени, како и актуелните уметнички тенденции, влијаат на тоа низ каква призма ќе се согледува вредноста на едно дело. Културните и естетските модели на македонската драма од крајот на XIX и на почетокот на XX век во однос на творечките, културните и идеолошки процеси, во поширока културолошка рамка, се сврзани со определениот карактеристичен историски момент, којшто ги обликува нејзините литературните специфики. Развојните патишта на драмата, во овој период, во однос на тематските, естетските и идејните карактеристики, се одвивале право пропорционално со општествено-политичките услови на територијата на Македонија. Во драмите создавани во овој период се бележи истовремено учество на уметноста и револуцијата. Во естетиката на овие драми, уметноста и книжевноста се преплетуваат со општествено-политичките и историските процеси, со религијата и фолклорот: „Секое книжевно дело е естетски објект и заедно со останатите негови комуникациски функции, кои се иницијално вградени или отстранети, ги поттикнува читателите да ја согледаат заемната врска меѓу формата и содржината“ (Калер, 2012, 38). Затоа и револуционернополитичка ангажираност, која има цел да ги привлече и да ги придобие гледачите кон својата кауза, станува основната причина за егзистенција на оваа драмска уметност.

Фолклорот во драмските текстови претставува веќе смислен акт од авторите: да се слушне звучниот македонски говор, да се истакнат велелепните убавини и дострели на македонскиот народен мелос, игра и изведба (Јаќовски, 1990, 35). Преку внесувањето на фолклорот и присуството на битовите елементи во овие текстови, било свртено вниманието на широката јавност за македонското културно и духовно богатство. Паралелно со 
фолклорот се преплетуваат актуелните револуционерни и општественополитичките процеси и пораки.

Драмскиот опус создаден во периодот од крајот на XIX и на почетокот на XX век изобилува со фолклорни естетски елементи. Сепак, во поглед на претходниот период, кога се јавуваат првите знаци на будење и стремежот за афирмација на фолклорното богатство на македонскиот народ, во овој период повеќе се забележува афирмација на културниот и на националниот идентитет преку една колективна револуционерна борба, којашто се јавува како лајтмотив и на книжевен план, така што фолклорот најчесто има секундарна улога во драмското дејствие, но сепак изразува силни естетско-идеолошки принципи. Историските, општествените и фолклорните појави, кои се вклучени во овие драми преку нов уметнички контекст, се трансформираат во естетски елементи, адаптибилни на уметничкиот текст.

Фолклорот е искористен како естетски модел за нивното структуирање и за адаптирање со општествената реалност, помагајќки му на гледачот/читателот полесно да се идентификува со текстот што е напишан/изведен. Кај сите драмски автори од првата генерација (Чернодрински, Молеров, Цепенков, Хаџидинев, Н. Македонски...) се чувствува обидот да ја сочуваат и да ја афирмираат народната мудрост на македонскиот народ. Тие црпат инспирација од сите облици на македонската народна традиција и култура, трансформирајќи ги во нов естетски облик. Фолклорните елементи се суптилно вметнати, речиси, во секој драмски текст од овој период, но тие не се видливи само во текстот, туку и при претставувањето на драмскиот простор и време.

Духовноста, односно христијанската традиција, е една од главните идентитетски одлики на македонскиот народ, поради тоа не е ни чудно што оваа традиција преку одредени форми и понатаму живо се јавува и во книжевноста. За време на отоманското владеење религијата е многу тесно сврзана со националното чувство. Тоа може да се проследи и во многу драмски текстови, каде што можат да се забележат христијански елементи најчесто претставени преку симболи, слики, илузии, наративни искази и сл. Во револуционерно ангажираните драми од овој период, преку одредени фолклорни елементи, често е интерпретиран христијанскиот дух изразен преку верувањето и верата, како и преку мноштво народни облици, особено со вметнувањето на: благослови, клетви, поговорки, пословици, обичаи и други форми на народни верувања, кои создаваат специфичен естетски ефект во поетскиот дискурс. Фолклорните елементи во драмскиот текст добиваат нова димензија и автентична естетска валоризација.

Една од драмите со најизразена фолклорна естетика, создадена во првата фаза од македонската драмска уметност, е драмата „Црне војвода“ од истакнатиот македонски фолклорист Марко Цепенков. Во неа доминираат бројни: благослови, клетви, пословици и поговорки, а употребата на народен говор само уште повеќе ја истакнува фолклорната естетика на оваа драма. Јазикот, како средство за естетско произнесување на творечките релации, секогаш помага во создавањето на јасна слика за атмосферата на дејството. Јазикот на Цепенков во оваа драма е уникатен, архаичен, мелодичен, кој не се 
говори надвор од неговата естетика. Преку ваквиот специфичен естетски израз особено се нагласуваат идентитетските обележја на македонскиот народ, што во суштина е и првичната идејна замисла на овие драми. Фолклористиката е тесно сврзана и со дејноста на Димитар Молеров, што е воочливо и во неговиот драмски опус. Користењето на фолклорот, што претставува тема за себе, е авторска тенденција во согледување на битовата драма, која извира од народот и животот и е нивна верна слика (Молеров, 1993, 378). Драмските уметнички творби на Молеров имаат високи фолклорни естетски карактеристики што само ја потврдува тезата дека во овој период се создавале и дела со естетска, а не само со агитаторска вредност.

Како што напоменавме, речиси, сите драми од овој период изобилуваат со фолклорно естетско надополнување. Во продолжение ке издвоиме дел од кратките фолклорни жанрови застапени во револуционерно ангажираните драми од крајот на XIX и на почетокот на XX век.

\section{Пословици и поговорки:}

\section{* „Црне војвода“" - Марко Цепенков}

„...со гола рака змија не се фаќа“ (Цепенков, 1972, 265)

„Наведена глаа, синко, сабја не ја сечит“ (Цепенков, 1972, 269)

„...вода спие, душмано не спие... “ (Цепенков, 1972, 271)

„... клин - клин тера“ (Цепенков, 1972, 281)

\section{* „Македонска емиграција“ - Војдан Чернодрински}

„...оној што гони два зајака и двата ги испушта“ (Чернодрински, Т. 1, 1976, 61)

\section{* „Македонска крвава свадба““ - Војдан Чернодрински}

„,...рибата в море, тавата на оган!““(Чернодрински, 1928, 11)

\section{* „Новиот даскал“ - Димитар Г. Молеров}

„За даскалот речено, за мачката печено“ (Молеров, 1993, 24)

„Краставите магариња преку девет рида се надушуваат“ (Молеров, 1993, 48)

* „Ајдучка полјана“ - Димитар Г. Молеров

„Ум царува, ум робува, ум шатки пасе““ (Молеров, 1993, 124)

\section{Благослови:}

\section{* „Црне војвода“ - Марко Цепенков}

„Честити нека ти се и госпо да ти поможит да свршиш оваа работа“ (Цепенков, 1972, 265)

„Дал ти госпо добро синко Ѓеорѓи“ (Цепенков, 1972, 279)

„...дај боже здравје... “ ( Цепенков, 1972, 286)

\section{* „Македонско востание“ - Никола Н. Македонски}

„Помогни бог на народниот спасител“ (Македонски, 1887, 74)

„Да даде господ да ги победиме нашите врагови и мачители“ (Македонски, $1887,75)$

\section{* „Од глаата си патиме“6 - Војдан Чернодрински}




\begin{tabular}{|l|}
\hline „Дал ти бог добро, керко...“ (Чернодрински, Т. 1, 1976, 12) \\
„Помози бог, брате!“ (Чернодрински, Т. 1, 1976, 35) \\
„Е, аирлија нека ти е, да се кердосаш“ (Чернодрински, Т. 1, 1976, 47) \\
„Македонска крвава свадба“ - Војдан Чернодрински \\
„Ајрија да е, со здравје да се јадит, до година појке... “(Чернодрински, 1928, \\
„1) „Робот и агата““ - Војдан Чернодрински \\
„Да ти се многу години...“ (Чернодрински, Т. 1, 1976, 119) \\
„Ајдучка полјана“- Димитар Г. Молеров \\
„Господ на помош!“ (Молеров, 1993, 163)
\end{tabular}

\begin{tabular}{|c|}
\hline Клетви: \\
\hline * „Македонско востание“ - Никола Н. Македонски \\
\hline „Бог да ги убие тие читаци!“ (Македонски, 1887, 81) \\
\hline * „Од глаата си патиме“6 - Војдан Чернодрински \\
\hline „Ѓаол да го земит!““(Чернодрински, Т. 1, 1976, 21) \\
\hline * „Новиот даскал““ - Димитар Г. Молеров \\
\hline „Ова дете ќе ме изеде, црна земја да го изеде!““ (Молеров, 1993, 44) \\
\hline $\begin{array}{l}\text { „Да те удри црна сипаница, та мајка ти да те посипе со шепа црна земја!“ } \\
\text { (Молеров, 1993, 47) }\end{array}$ \\
\hline „Чума црна те ударила, да те удри!“( (Молеров, 1993,47$)$ \\
\hline * „Ајдучка полјана“ - Димитар Г. Молеров \\
\hline „Да ви се запустат и столовите, и главите, и сѐ“ (Молеров, 1993, 125) \\
\hline „Ај, мечки го изеле!“‘ (Молеров, 1993, 134) \\
\hline „Господ да го отепа!““ (Молеров, 1993, 164) \\
\hline „Чума го изела да би го изела!““ (Молеров, 1993, 176) \\
\hline
\end{tabular}

Како примарни фолклорни естетски објекти, кои се јавуваат речиси во сите драмски дела од овој период се народните песни. Цела една антологија од народни песни е вметната во драмите од крајот на XIX и на почетокот на XX век. Тие најчесто не се во функција на украс, туку имаат прагматична улога надополнување на драмската нарација и афирмација на македонската борба за слобода и самобитност. Преку интерпретацијата на народната песна за потребите на драмските текстови, таа добива нова естетска димензија. Сепак, основната цел, често била создавање на сценски колаж во кој се вметнувале фрагменти или цели песни од популарни народни песни што веќе имале свои мелодии, преку кои истовремено се формирала релативно самостојна фабуларна целина, која го одразувала конкретниот историски миг (Алексиев, 1984, 48).

Народните песни во драмите од крајот на XIX и на почетокот на XX век најчесто служеле како мотивско-тематска инспирација, како што е на пример драмата „Црне војвода“ од Цепенков, која е инспирација од народна песна за Спиро Црне војвода, но се јавуваат и како естетско надополнување на драмскиот наратив: „Народните песни во авторските драмски творби се наоѓале во функција на своевидна порака; за зголемување на илустративноста 
на драмскиот исказ, за комплетирањето на битовиот амбиент во кој се изведува драмското дејствие, како и за сродни намери и функции“ (Саздов, 2001).

Народните револуционерни, комитски и борбени песни, авторите често ги вметнувале за пред гледачите да се истакне револуционерниот ентузијазам. Такви примери се забележуваат во неколку драми од оваа епоха, како на пример: во „Црне војвода““, „Спиро војвода пее:“,,...Македонија вика/јунаците да стана(т)/ со ножеи и пушќи (2)...“, (Цепенков, 1972, 293) додека Кочо Левенов во „Ајдучка полјана“ на Молеров пее: „Мене ми е мајка таа крива пала/Развеј барјак, Кокалич војводо!“ (Молеров, 1993, 217).

Во драмите се пеат и патриотски песни, преку кои авторите, на еден суптилен начин, се обидуваат да допрат до најдлабоките дамари на гледачите, за да можат да ја сфатат потребата од бунтовност и борба за сопствената и за колективната слобода. Поробената, односно сѐ уште неослободената земја, во песните претставува клучен аргумент за борбено единство на националната заедница во нејзината борба за социјална и национална правда и слобода (Пановски, 1991, 56). Во „Македонска крвава свадба“ Нико, Гуре и Арсе пеат: „Македонија, мајко мила,/ Страдна земјо, света,/ Много мајко, си теглила/ В м'ки и несрета!“. И во „Македонско востание“ востаниците пеат песна за својата мила татковина: „Од небото излегува/ Во Македонија слегува/ Светлозорна мвезда/ Македонска надежда; Македонци огрева/ ... Македонски јунаци/ Сите крв да пролееме/ И да изумреме,/ Заради татковината/ И нашата слобода“ (Македонски, 1887, 73).

Неретка е и појавата на љубовни песни. Таков е примерот со народната песна „Руса мома, русин брала“ (Чернодрински, 1928, 22-23) што ја пее Цвета во „Македонска крвава свадба“, откако се враќа од од љубовната средба со својот сакан Спасе; или во „Ајдучка полјана“: „Умирам да те целивам/ Кај што ти стои ѓерданот,/ Умирам да те прегрнам/ Кај што ти стои коланот“ (Молеров, 1993, 158). Исто така, во „Ајдучка полјана“ се јавува и една приспивна песна: „Нани, мило, нани/ Мама ке си дојде,/ Млекце ќе донесе./ „Луле, пиле, луле,/ Дојди, сонче, дојди,/ Дојди од горица...“ (Молеров, 1993, 172).

Овие песни најчесто имаат определена драмска функција и се користени како гола и исфорсирана илустрација на драмското дејство, со исклучок, се разбира, на оние драмски дела, чија основна цел е, во драмската форма, да го презентираат народниот мелос (Алексиев, 1984, 58). Фолклорните елементи во овие драми првенствено се вметнуваат за постигнување на поголем сценски ефект.

Иако драмските остварувања од крајот на XIX и на почетокот на XX век првенствено се ставени во функција на револуцијата и на борбата за слобода, сведувајќи ја литературата како средство преку кое се пренесуваат општествените случувања, изоставајќи ги уметничките вредности како секундарни, сепак, со внесувањето на фолклорот и со присуството на битовите елементи, се внел нов специфичен естетски израз препознатлив за нив, со што било свртено вниманието на широката јавност за македонското културно и духовно богатство. Националното во уметноста не се наоѓa само 
во материјалните фолклорни елементи, туку лежи во самиот дух на народот. Народот е носителот на општественото мислење, кое се формира околу едно дело и кое ја условува неговата перцепција. Уметничката перцепција е културен процес, кој се одвива во контекст на културата, чиј носител и творец е народот (Борев, 2008, 182). Револуционерно ангажираната драма од крајот на XIX и на почетокот на XX век се истакнува со прогресивни импулси за национален и за културен развој, поради што служи како главна алатка за идентитетска диференцијација на македонскиот народ. Сложените општествено-политички околности во Македонија, во дадената епоха, создале свои специфични насоки во духовниот и во културниот живот, што иницирале обликување на карактеристични особености во поглед на новите идејни и естетски тенденции во драмската книжевност, која претставувала вистинско огледало на актуелните случувања.

\section{ЛИТЕРАТУРА}

АЛЕКСИЕВ, А. (1984). Низ литературното минато и сегашноста: огледи. Скопје: Култура.

БОРЕВ, J. ( 2008). Естетика. Скопје: Македонска реч.

ДРУГОВАЦ, М. (1990). Историја на македонската книжевност ХХ век. Скопје: Мисла.

ЈАКИМОВСКА, Т. Маја. (2013). Книжевни и културни модели во македонската средновековна литература. Скопје.

ЈАК̈ОВСКИ, В. (1990). Развојниот пат на македонската драмска литература и односот на драмските автори кон фолклорот. Македонска драма XIX и XX век. Скопје: Македонска книга.

КАЛЕР, Џ. (2012). Книжевна теорија (сосема кус увод). Превод од англиски: Кристина Димовска. Скопје: ПОЕТИКИ.

ЛУЖИНА, Ј. (1995). Истроија на македонската драма - Македонската битова драма. Скопје: Култура.

Македонский, Н. (1887). Македонски - сжлзи или Злощастна Македония. Трново.

МИРОНСКА, Х. В. (2012). Литературни студии за македонскиот идентитет. Скопје: Институт за македонска литература.

МОЛЕРОВ, Д. (1993). Драми. Скопје: Мисла.

ПАНОВСКИ, Н. (1991). Театарот како оружје - Театарскиот модел на Чернодрински. Скопје: Култура.

САЗДОВ, Т. (2001). Функцијата на народните песни во драмите на Војдан Чернодрински. Војдан Чернодрински живот и дело. Скопје/Струга: Институт за македонска литература/ Дом на култура.

СТОЈАНОСКА, А. (2018). Театар: предизвик - студии и есеи. Скопје: Универзитет „Св. Кирил и Методиј“.

ТАСЕВСКА, Х. И. (2016). Идентитетот како дискурзивен феномен во словата од македонскиот литературен ХІХ век. Култура. бр.16, 114-124.

ЦЕПЕНКОВ, М. (1972). Материјали, литературни творби. Скопје: Македонска книга. 
ЧЕРНОДРИНСКИ, В. (1928). Македонска кървава свадба. София: Витоша.

ЧЕРНОДРИНСКИ, В. (1976). Собрани дела, I-IV. прир. Александар Алексиев. Скопје: Мисла.

Slavica Petrovska

\section{FOLK AESTHETICS IN THE REVOLUTIONARY DRAMA OF THE LATE $19^{\text {th }}$ CENTURY AND EARLY $20^{\text {th }}$ CENTURY}

Summary

Macedonian drama texts created in the late 19th and early 20th centuries, despite the dominant revolutionary-political ideological tendencies, abound with numerous folk aesthetic elements. Unlike the previous period of Macedonian literature, when the most noticeable is the awakening and the aspiration for affirmation of the folk treasure of the Macedonian people, in this period is notice an affirmation of the cultural and national identity through a collective revolutionary struggle. This revolutionary spirit also appears as a leitmotif of the literary plane, while folklore often plays a secondary role in dramatic action.

With the use of folk wisdom, the authors try to reinforce the aesthetic value of the plays by introducing numerous songs, blessings, curses and salutations characteristic for the Macedonian people of that period. By incorporating folkloristic elements into the revolutionary plays, the playwrights were able to more easily achieve their main goal affirmation of the Macedonian cultural and national identity. 